The goal of science is clear; it is nothing short of the complete interpretation of the universe.

Or as Muir has put it:

The great business of chemistry is to force men into close contact with some aspects of external realities and, with the help of her sister sciences, to remove everything that prevents the full vision of nature.

Arthur D. LitTle

\section{THE FUNCTION AND FUTURE OF THE TECHNICAL COLLEGE ${ }^{1}$}

THAT the education of the child through the first eight years of school should be at the public expense is a matter generally accepted as fundamental by every intelligent voter in this country. There are, however, those who insist that public funds should not be used in carrying on schools of secondary rank; and that the expense of college or advanced technical training should be met and universities sustained by the state is a proposition many would combat. The teaching of trades at public expense, a matter that a few years since was considered impossible by trades unions and society generally, is slowly but surely making its way in this country. If we are to witness, in the next decade, such advances in the scientific, commercial and industrial world as would appear commensurate with the progress of the past ten years, it will be largely due to the work of the technical schools, and colleges of science and engineering-institutions under state control as well as those on private foundations.

As the opportunity and field for such institutions are becoming vastly greater and broader and the need for technically trained men more and more apparent, the fact is also clear that the training in such schools is too narrow and restricted. This is but the natural revolt against the old scholasticism. From a college training in

\footnotetext{
1 Elaboration of an address before the Technical Education Department of the National Education Association, July, 1907.
}

letters merely, the tendency has been strongly marked in the opposite direction, and pure science and technique in the abstract has characterized the technical courses.

In these institutions men must be prepared, not alone to carry out the will of another; not simply to be exact machines to execute the plans presented to them. The product of these schools must possess initiative, imagination, individuality; they must be experts, leaders, investigators, executives; they must plan and lead, not follow merely; they must create as well as construct. In other words, continued progress means that technical education must produce executive engineers and industrial experts. For these men of the future we must rely upon the endowed institutions, of which there are all too few of high grade, as well as upon public institutions ranking with the former and offering all the advantages of study and research.

The time will soon be upon us when, forced to sustain a much greater population than we now have, and owing to keen competition with foreign countries, the industrial and commercial development of this nation will demand experts in many lines. The depleting of our forests not only robs us of timber needful in developing the arts, but in certain sections of the country will so affect the water supply as to produce regions dry and arid; the storing of water in reservoirs for purposes of power, consumption and irrigation is a matter hardly yet begun; the building of railroads, canals, electric lines; the bridging of rivers and the draining of swamps; the constructing of a system of highways and thoroughfares from city to city and throughout rural districts; the development of scientific farming, the greatest industry before our people to-day; the building of harbors; the perfecting of our great mining industries; these are some of the enter- 
prises for which trained men are needed, and the technical school must furnish them.

In using the term "technical college," there is implied a more extended field than that covered by the college of engineering as the latter is generally understood. In its broad aspects the technical college comprehends work in general science, in mechanical, electrical and civil engineering, mining and chemical engineering, hydraulics, architecture, steam, màrine and railway engineering, sanitary science, forestry, agriculture, horticulture and the various subdivisions of these comprehensive and inclusive phases of scientific and industrial life.

The very breaking up of any one of these several branches or subjects gives us at once the clew to the necessity for more intensive and more extended work in the departments they represent and shows clearly the necessity for training an increasingly large number of competent men. While many who might pursue technical courses are far removed from the special school, still the duty of extending and carrying on the work must rest in no small degree with these schools, as so few state institutions at present offer adequate courses in these lines.

In the old days before electricity was used as motive power or for purposes of illumination, when building construction was almost entirely with wood, and work in the arts demanded at best small quantities of iron and steel with little stone or brick and no concrete, when work by hand had not been supplanted by the laborsaving mechanical devices, when problems of transportation by land and water, of heating, lighting, water supply, sewerage and drainage, of bridge and road building, of scientific agriculture were as yet undeveloped, the demand for technical education was small. In the mechanical world the civil engineer was the man of the hour.
He who could establish a grade or construct a single span was in the front rank. Mechanical and electrical engineering courses, as such, were in embryo. The work of the mining engineer was done by rule of thumb. The "cut and try" method was applied in chemistry and architecture. Sanitary science was in an elementary stage. The study of hydraulies was theoretical rather than applied. Forestry, agriculture and horticulture were carried on in the belief that "nature must take her own course."

But the application of scientific principles in the arts and industries has made possible an evolution that has resulted in a revolution. More and more we have differentiated our lines of work, until what originally appeared to be a field in itself is now broken up, and the expert is he who spends a lifetime upon only one of the problems of a given field of knowledge. As Willam C. Gannett says: "The man of science, and to-day more than ever, if he would add to the world's knowledge, or even get a reputation, must be, in some one branch at least, a plodding specialist."

There is, however, to this argument another side that must be considered. While in an earlier day the work was of a general character, and the special phases of science as yet undeveloped, this very specialization of which we have been speaking has brought about a strong reaction. Constant touch with the special phases of work, concentration upon a comparatively narrow field of human interest, can not but have its effect upon the individual. This fact receives abundant exemplification constantly and illustrations need not be multiplied. Too often we find the technical expert or man of science a technical expert merely. If by nature he is narrow, his training in the schools only tends to enhance this narrowness. Of art or letters, music or drama, he knows little and cares 
less. Business is a bore, history a closed book, and he has little in common with society and men and things. As the world develops he knows of this development, if at all, only from the standpoint of the growth of his own science. If he attempts aught outside his field, he fails.

This, then, is the anomaly. That while in the early days of applied science, to be an engineer implied a general knowledge of such principles of the subject as were known, the development of scientific and technical thought and appreciation and the birth of many courses produced extreme specialization. Hence we find the scientific man of to-day troubles himself, not so much with the broad phases of the subject as with a specific part. We have already reached the danger point and the machine engineer, the natural result of our present system, must soon be displaced by the thinking engineer. The artisan is to go down before the artist-artisan. Thought must take precedence over imitation. The necessity for a broader and more general knowledge upon which the specialty may with safety be constructed, is the argument here being presented.

With this main issue in mind, let us turn for a moment to the consideration of the number of high-grade institutions in this country wherein are offered courses of a technical nature.

A detailed study shows that out of fortytwo state universities (the total number in the United States), thirty-six offer technical and engineering courses. Of other colleges and universities of a public, endowed or private character, there are sixtythree offering such courses, while there are forty-five special schools of technology and science; in all a total of one hundred and forty-four institutions offering technological courses.

Of the thirty-six state universities offering these courses, six only may be classed as of the first order. Six of the sixtythree additional colleges rank as first-class institutions, while fourteen of the forty-five special schools of technolngy are in class one. In this latter number, the Naval Academy at Annapolis and the Military Academy at West Point are included.

of the six state universities mentioned, all offer courses in electrical, civil and mechanical engineering, three offer courses in architecture, five in chemical engineering, four in agriculture, three in sanitary, two in mining and three in railway engineering, two in metallurgical engineering, one in naval architecture, two in forestry, one in marine engineering, one in irrigation and one in ceramics.

The six additional colleges of public and private nature offer courses as follows: six in electrical, six in civil and five in mechanical engineering, three in architecture, three in chemical engineering, two in agriculture, two in sanitary, four in mining and three in railway engineering, one in metallurgical engineering, two in naval architecture, two in forestry, two in marine engineering and one in horticulture.

In the fourteen special schools of technology, we find nine offering courses in electrical, eight in civil and nine in mechanical engineering, five in architecture, three in agriculture, two in sanitary, five in mining, one in metallurgical and five in chemical engineering, one in forestry, one in railway engineering, one in naval architecture, one in horticulture and one in ceramics.

This gives us a total for the twenty-six educational institutions of twenty-one offering courses in electrical and twenty each in civil and mechanical engineering, eleven each in architecture and chemical engineering, nine in agriculture, seven in sanitary, eleven in mining, seven in railway and five in metallurgical engineering, four in naval architecture, five in forestry, three in ma- 
rine engineering, two in horticulture, one in irrigation and three in ceramics.

The combined courses offered by state universities, other public and private colleges, and the special technical schools (one hundred and forty-four institutions) are as follows : ninety-one in electrical, one hundred and thirteen in civil and ninety-four in mechanical engineering, twenty in architecture, fifty-nine in agriculture, fourteen in sanitary, fifty-two in mining, four in marine, ten in metallurgical, thirty-four in chemical and seven in railway engineering, four in naval architecture, four in irrigation, nine in forestry, twelve in horticulture, five in textiles, and five in ceramics.

These facts show the meager opportunities offered for intensive technical work, especially in the light of our rapidly developing resources. The mere fact that there are one hundred and forty-four institutions where education of the character indicated may be had, is not at all an answer to the point made. In most of these institutions calling themselves colleges, and in many of which the traditional subjects are well taken care of, the equipment, the location, the general facilities and the character of the instruction given in technical lines are not such as to fit for leadership or for executive positions, or to equip for expert work, nor are the humanities always so taught as to develop richness of mind.

What has been said of the narrowing influences of courses of study in schools of technology of to-day, applies in greater or less measure to every such institution in the country. Even those of greatest reputation are not free from this criticism. Some of these colleges are breaking the bonds of tradition and are broadening their curricula. The fact remains, however, that if we are to equip, not machines, but men, if the product of the school is to be first a man and then an engineer, it follows that the conservative measures of the past must be disregarded and that we must demand a more logical treatment of our technical college schedules.

That the training given in the technical college be not over narrow and restricted, to the science, mathematics, drawing and shop work must be added such of the humanities as experience may show to be essential. The graduate of an engineering college or of a school of technology frequently finds himself in possession of suffcient facts connected with his profession, but with a knowledge of the language he uses so inadequate as to seriously handicap him in pursuing his vocation. The business side of his education he also finds, when too late, has been sadly neglected. To adequately express oneself and to perfectly understand all business forms, such as papers of conveyance, deeds, bills of lading, etc., are matters to be ignorant of which is absolutely inexcusable. Details of common law, training in questions of national and political economy, of general history and of commercial geography are fundamentally essential.

Herein is where the failure is so often made. The specialist can perform the task allotted to him, he can construct the plant, install the equipment, but can go no further. The management of the enterprise, the business side of the project, he can not grasp. For this purpose a business man is required, and the latter, having no acquaintance with the technical features involved, makes failure of his administration. The engineer must be an executive engineer. His training must be such as to enable him to tie together the various specialties. He must understand accounting and know how to make proper apportionments; in other words, he must be familiar with the commercial phases of his profession; he must have a knowledge of business methods, of political and economic conditions, of the development of trade and in- 
dustry. He must know thoroughly the commercial side of his problem.

But if technical courses are thus broadened, adjustment must be made somewhere. No more can be crowded into the four years now required for graduation from a technical or engineering school. Must, then, these additional lines of work be demanded of technical students, and if so, how shall the schedules be adjusted?

Three alternatives present themselves as partial answer to the last question. First, the lengthening of the professional course to five or six years, making it graduate in character and on a par with graduate or professional schools of medicine or law. Second, the adding of two years to the present high-school courses now preparing for advanced technical work, thus enabling students to enter the technical college upon a much better foundation than at present. Third, the elimination of the non-essentials from the present four years' courses, thus leaving more time for additional necessary work.

The argument advanced by advocates of the first method is that the four years of regular college work is not sufficient. That to be adequately trained implies ultimately the lengthening of the college course to five or six years. Each year brings a greater store of knowledge to be taught and with this additional knowledge comes the understanding that to push the man through his course is to start him on the road to inefficiency. Especially must those who are to be leaders, the "trail blazers," the executives, the experts, be given advantage of a longer course.

The claim is made that after eliminating the non-essentials there will not be sufficient time in which to present the subjects of the special line being pursued and such of the humanities or so-called culture subjects as were previously suggested. English alone must be granted considerable time, as an appreciation of good literature, a taste for the best that has been written, is essential to growth, whoever the man and whatever his profession. The student who in school and regardless of his trend of thought, is not given the opportunity of putting himself on friendly terms with the best in literature, is being robbed of one of the tools most necessary to advancement, and an element of the greatest pleasure and profit. On the other hand, so much must be added each year, as the discoveries and developments in science are made, that these alone may more than compensate for the eliminations.

Considering the second point, it would seem that there are many and strong arguments in favor of the lengthening of the high-school course to six years, such arguments applying with equal force to both traditional and manual-training high schools. But the lengthening of the preparatory course implies at once one of three alternatives. (1) A six-year preparatory course, in which the subjects are of secondary grade, without regard to lengthening of the college course thereafter. (2) A six-year preparatory course wherein certain preliminary college work is taken up, the regular college course to be either two years or four years in length. (3) $\mathbf{A}$ six-year course to be followed by a six-year college course. These propositions will receive no extended consideration at this time.

If the proper equipment and courses could be supplied in the high school, the students had better spend six years therein, as many who seek the technical and engineering college are so immature as to be unable to adjust themselves to the changed atmosphere, and go down and out in the first few weeks of school. Many have not found their level on leaving high school and are not adapted to the work to which they aspire. At much less expense than at 
college, less danger, and with a better opportunity to "try out" his powers and determine his inclinations, the boy may spend his added two years in high school.

It happens many times that the moral atmosphere of the college is undesirable, especially so to the boy fresh from the small high school. Moreover, the quality of the instruction offered in the first two years of many of the larger institutions is far inferior in grade to that which may be had in the well-conducted high school.

On the successful completion of these two years of work, a diploma should be given. It would then be possible to advise the student as to whether or not further college work would be to his advantage.

While there is much truth in the foregoing argument, it remains to be said that it is next to impossible, under present conditions, to induce those best qualified for the work to continue more than four years beyond the secondary school. Considering the readjustment of schedules, it is certain that there are many husks that may be thrown out. This matter of elimination must be taken up from the very beginnings in school work. All along the line (perhaps in the technical school less than elsewhere) much time is spent upon those things that are neither practical nor cultural. Then, too, it is quite as common an error to underestimate the ability of the student as to overestimate it, and much that is now taught would be absorbed without regard to teacher or course of study if the student were allowed to do so.

Year by year, new discoveries and researches, greater advances and broader developments, add a vast fund of material to the technical courses. Since there is a maximum limit to the years one should spend in training, we must constantly trim away the unnecessary material. Only the essentials can remain, and through organization and systematization, through care- ful selection and concentration of effort, not only may the student in training get from his four years at school more than he now receives of the technical side of his work, but he may also broaden his vision and become better prepared than he now is to take up the duties of his profession. For, to quote MacDonald in Sir Gibbie:

There is a great deal more to be got out of things than is generally got out of them whether the thing be a chapter in the Bible or a yellow turnip, and the marvel is that those who use the most material should so often be those that show the least result in strength of character.

Through this readjustment more shop work may be given than is now offered. In some schools the time devoted to shop courses is at a minimum, the idea being that a knowledge of shop processes can be gained later. To prepare fully for technical work the various shop processes should be understood, even though they be not taken up in detail, that the proper connections may be made. Considerable attention should be given to the construction of apparatus, instruments and machines. In the technical school is offered the best of opportunities for reconciling the methods of commerce with those of the educator. The two should dovetail.

There is another reason why every student in a technical school should have contact with and thoroughly master each machine and process. Too often the graduate of the school seeks a position in the office or at the desk. $\mathrm{He}$ does not believe in hardening his hands or soiling his clothes. He has not been in the habit of "taking off his coat" while in school. The student who has mastered the shop process has learned how to work, and appreciates the joy of working, and he is neither afraid nor ashamed to begin his professional career in an inferior position and thus lay the foundation for advancement.

All technical college courses then, under 
these conditions, would be rather more topical and more intensive than at present, leaving much repetition and detail, and particularly those subjects that will not find application later on, to be taken up by. the student at his option, after leaving the school.

But to develop technical courses to the point of greatest efficiency it will not only be necessary to offer a suitable program of studies, and to perfect an organization and equipment, but instruction must come from men who are broadly trained, scholarly and cultured, who are educational experts and administrators and who have achieved success in their fields of work. To secure such men it will be necessary to offer financial consideration such as to induce them to enter the educational arena instead of devoting their time to commercial practise.

A study of the engineering college will show that everywhere, and especially in Germany, a strong reaction is taking place, and the feeling is growing, that a welltrained engineer must be a man broad in his sympathies and possessing a knowledge of people and things that shall give him place anywhere and always. The Emperor William on the occasion of the Charlottenburg celebration used these words to indicate what was, to his mind, the connection between the technical high school and the engineering college:

In the relation of the technical high schools to the other highest educational establishments, there is no opposition of interests, and no other competition than this, that each of them and every member of them for his own part, should do full justice to the claims of life and science, mindful of the words of Goethe: "Neither to be like the other, but each alike to the highest." How is this to be done? Let each be complete in itself.

Finally, in the technical college as elsewhere, the ultimate purpose of the training offered is for service. But the service rendered must be given, not with the hope of material gain only or of selfish reward.
Recent events in our own country have shown us most clearly a regrettable lack in our present social attitude. We have men -trained specialists, professional, commercial, technical-and we need more of them, but if we are to meet successfully the present state of social unrest and solve the economic, political and moral problems that confront us, these must be men of broad vision; men who realize the needs of society and are willing to assume to the full their individual and joint responsibilities. The college of engineering must do its part by broadening its purely technical character on the lines which I have attempted to indicate.

But the proper results in technical education can not be obtained without work and there will be much opposition. We must be open-minded always, definite in our purposes and willing to stand alone if in the right. What Burke says of Parliament finds application with us in America, whether it be in politics, in the religious world or in education:

Their one proper concern is the interest of the whole body politic, and the true democratic representative is not the cringing, fawning tool of the caucus or the mob, but he who rising to the full stature of political manhood, does not take orders but offers guidance.

A. H. Chamberlain

Throop Polytechnic Institute

\section{RECENT SANITARY LEGISLATION IN KANSAS}

As an illustration of the advanced work that is being done in the interests of sanitation throughout the middle west, a report on the recent legislation, affecting the Kansas State Board of Health, may be of interest.

1. At the recent session of the legislature an amendment to the present Food and Drugs Law was passed, largely increasing the authority of the Board in making rules and regulations, and defining standards of purity and strength for quality of foods and drugs.

2. A comprehensive law was passed, providing for sanitary inspection in places where 